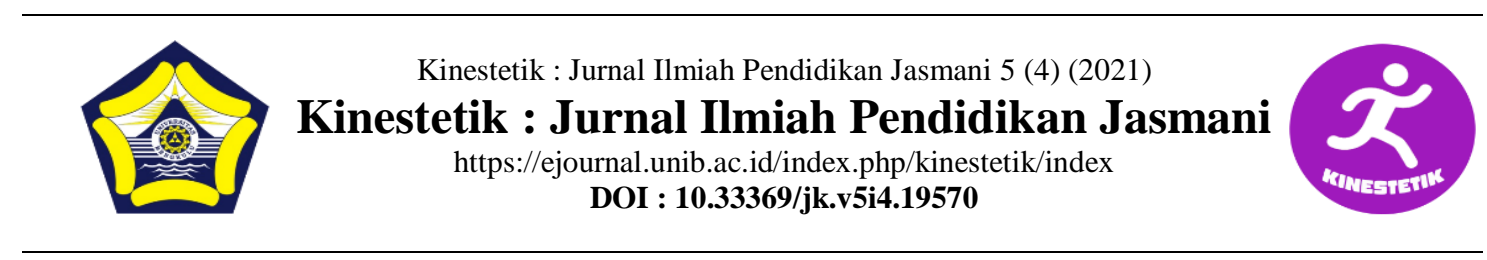

\title{
LIFESTYLE OF INDONESIAN EDUCATION UNIVERSITY STUDENTS DURING THE COVID-19 PANDEMIC
}

\author{
Lilis Komariyah ${ }^{1 *}$, Lucky Angkawidjaja R $^{2}$, Agus Gumilar ${ }^{3}$, Burhan Hambali ${ }^{4}$, \\ Tri Martini ${ }^{5}$, Tasya Aulia Rahma ${ }^{6}$ \\ ${ }^{123456}$ Department of Sports Education, Faculty of Sports and Health Education, Indonesian \\ University of Education, Bandung, Indonesia
}

\section{Article Info}

Article History :

Received : Desember 2021

Revised : Desember 2021

Accepted : Desember 2021

Available online :

Desember 2021

\section{Keywords:}

Lifestyle, Health

Education, COVID-19

Pandemic

\begin{abstract}
The purpose of this study was to obtain empirical data related to student lifestyle analysis at the Indonesia University of Education during the COVID-19 pandemic. The method that will be used in this research is descriptive. By creating a database related to student physical activity at the Indonesian Education University during the COVID-19 pandemic. The instrument that will be used in this research is an instrument developed by Douglas \& Donna named Fantastic Lifestyle Assessment. The results of the analysis show that the lifestyle or lifestyle of students within the Indonesian Education University during the Covid-19 Pandemic showed poor results where out of a total of 274 respondents $38 \%$ were in the low category and there were even 2 respondents in the dangerous zone category, and only a total of $13 \%$ were in poor condition. ideal and $48 \%$ are in the sufficient category. The Covid-19 pandemic has greatly disrupted the stability of lifestyle conditions through the parameters measured, namely the condition of family and friends, physical activity, nutritional or nutritional intake, cigarette consumption, alcohol consumption, sleep quality and stress levels, personality, ability to understand events, and satisfaction with career.
\end{abstract}

Corresponding address : Jl. Dr. Setiabudi No.229, Isola, Kec.

Sukasari, Kota Bandung, Jawa Barat

*Corresponding email : liliskomariyah@upi.edu
ISSN 2685-6514 (Online)

ISSN 2477-331X (Print) 


\section{INTRODUCTION}

The Covid-19 pandemic is one of the first and foremost health crises in the world. Many changes and things that have never happened and happened in this covid-19 pandemic. For example, airport closures, school closures, from elementary school to college level, shop closures, implementation of WFH and so on (Purwanto et al. 2020). The restrictions on outdoor activities implemented during the COVID-19 pandemic have led to changes in people's lifestyles, the impact of which is the reduced number of people's participation in physical activities and changes in diet. Quarantine/self-isolation results in reduced levels of physical activity similar to space exploration and containment (Peçanha et al. 2020). Research shows that physical activity is a high risk factor for major disease morbidity. Worldwide, $31 \cdot 1 \%$ (95\% CI $30 \bullet 9-31 \cdot 2)$ adults are physically inactive, with proportions ranging from $17 \cdot 0 \%$ ( 16 - 8-17 -2) in Southeast Asia to about 43\% in the Americas and the eastern Mediterranean. Inactivity increases with age, is higher in women than men, and increases in high-income countries (Hallal et al. 2012). Another study stated that of 2,426 children and adolescents (boys, $51.2 \%$; girls, $48.8 \%$ ), overall, the average time of physical activity decreased dramatically, from 540 minutes/week (before the pandemic) to 105 minutes/week (during the pandemic), resulting in an average reduction of 435 minutes. For the record, during the pandemic, the prevalence of physically inactive students increased from $21.3 \%$ to $65.6 \%$. Digital activity increased significantly during the total pandemic (average +1730 minutes [or approximately 30 hours] per week) (Xiang, Zhang, and Kuwahara 2020). Decreased physical activity that is limited due to the implementation of strict quarantine can have metabolic effects that can increase the risk of diseases such as diabetes, cancer, osteoporosis, and cardiovascular disease (Lippi, Henry, and Sanchis-Gomar 2020). The percentage of the population using the internet for the last three years has always increased for urban areas in 2016 (35.86\%), 2017 (43.36\%), and 2018 $(50.92 \%)$ while for rural areas, namely 2016 (14 .23), 2017 (19.87\%), and 2018 (26.56\%), the combined rural and urban data shows $25.37 \%$ for $2016,32.34 \%$ in 2017, and $39.90 \%$ in year 2018 (Katalog BPS : 4501001 n.d.).

Youth participation in sports has enormous potential in their age development (Côté and Hancock 2016). It is generally believed that through sport, children and youth learn values and skills that will serve them well as they prepare for the rest of their lives. Unfortunately, many programs are not well structured or implemented in such a way that life skills that can be learned in sport are transferred to other skill domains (Danish et al. 2004). A number of community-based programs often target underserved youth, as this population is particularly vulnerable to not achieving optimal development. More specifically, underserved adolescents have been identified as children and adolescents who are at higher risk of unhealthy and risky behavior due to various combinations of low socioeconomic status and lack of access to services and facilities. As a result, underserved youth are more likely to experience a number of unhealthy developmental outcomes (Forneris, Whitley, and Barker 2013).

\section{METHOD}

The research method that will be used in this research is descriptive survey analysis. The use of the descriptive survey analysis method is assumed because basically the main goal in this study is to 
analyze the lifestyle of Indonesian Education University students during the covid-19 pandemic. How are the daily activities of students at the University of Education Indonesia, including physical activity, rest conditions, stress management, and social activities carried out during the COVID-19 pandemic. In addition, the specific purpose of this research is to obtain empirical evidence about student lifestyles during the covid-19 pandemic so that it can be an illustration and recommendation for the community at the Indonesian Education University.

\section{Population}

The population is a general object which is the entire data source of a study and has the general characteristics of the object to be studied. Thus, the population will provide information about the needs in the study. The population of the research subjects were all first-year students at the Indonesian Education University.

\section{Sampling Procedures}

The sample in this study was 274 respondents $((\mathrm{P}=173 ; \mathrm{W}=101)$ level one of eight faculties within the University of Indonesia Education.

\section{Research Instruments}

The main instrument that will be used to collect data in this study is the Fantastic Lifestyle Assessment, this instrument was made by Dr. Douglas Wilson from the Department of Family Medicine, McMaster University Canada. This instrument contains nine indicators related to lifestyle such as physical activity, rest, stress, social relations, nutrition, and others. The assessment of the instrument resulted in 5 categories of assessment (instrument attached), in the process the instrument was validated linguistically by a linguist, namely Wulandari, M.Pd. The data retrieval process is carried out online or online with the googleform media and is forwarded to all students within the Indonesian Education University.

Google link Research instrument form: https://forms.gle/v7ocH8XHKebWB2NU6

\section{Design or Data Analysis}

The data is calculated using descriptive statistics, the results of the survey conducted are a total of 274 student respondents who have responded to the research, and the following is the percentage of respondents data according to the parameters measured, namely the condition of family and friends, physical activity, nutritional intake or nutrition, cigarette consumption, alcohol consumption, sleep quality and stress levels, personality, ability to understand events, and career satisfaction.

The following is the standard of assessment and the meaning of the scores obtained for lifestyle measurement :

If your score:

42 - 50 - Very Good

35 - 41 - Good.

30 - 34 - Enough

20 - 29 - Somewhat low

0 - 19 - Being in a danger zone

Based on the results of data analysis obtained from respondents who gave responses, the following data were obtained 12 students in the Very Good category, 25 students in the Good category, 132 students in the moderate category, 103 students in the low category and 2 students in the Hazard Zone category.

\section{RESULT AND DISCUSSION}

Outdoor activities that are limited and implemented during the COVID-19 pandemic have caused changes in people's 
lifestyles in the form of decreased participation in physical activity and changes in diet. Quarantine/self-isolation can lead to decreased levels of physical activity (Peçanha et al. 2020). The decrease in the level of physical activity was accompanied by an increase in sedentary behavior. A sedentary lifestyle can increase appetite which is associated with hormonal changes, nerve mediators, and glucose metabolism patterns (Marichi et al. 2020). In addition, appetite can also be affected by the stress caused by selfquarantine at home during the pandemic. These dietary changes tend to lead to overeating behavior with high-calorie food choices. A study found that there was a significant increase in the intake of fried foods and sweets during self-quarantine during the COVID-19 pandemic (RuizRoso et al. 2020). In addition, the importance of physical activity during the Covid-19 pandemic can reduce stress levels, the physical activity of students who have high physical activity has a lower cortisol hormone, indicating that they are not easily anxious. (Nuryadi, Negara, and Roring 2015), physical fitness contributes $4.9 \%$ to the hormone cortisol (Darajat, Nuryadi, and Gumilar 2017).

Global issues related to a healthy lifestyle have become a reference for many countries and institutions to always encourage people to be actively involved in physical activity, especially through sports activities. Active living provides many health benefits. In addition to keeping away from various physical ailments, exercise can also keep away mental disorders such as depression. The culture of sports activities in Indonesia has begun to erode, even though the culture of sports is one of the important steps of national development in the field of sports because it is in contact with the widening level of community participation, so that efforts to improve the progress of people's lives as a whole can be achieved (Ma'mun 2016). When children and youth are enrolled in a sport, it is believed they will benefit from their experience. Parents, coaches, and school administrators often assume that in addition to physical nervousness, children and youth will acquire important life skills (Gould and Voelker 2010). Physical activity is expected to reduce anxiety and improve concentration. It has been proven that regular physical activity has the same impact on mental health as physical fitness (Nuryadi et al. 2019).

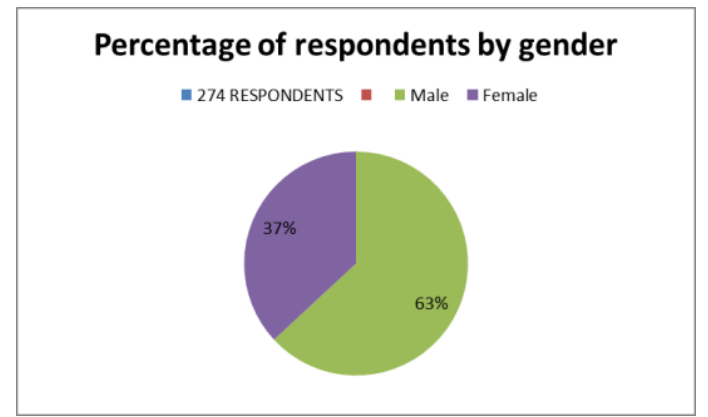

Figure 1. Percentage of respondents by gender

Based on gender, women filled out more questionnaires than men, where the percentage of female respondents was $63.1 \%$ and male respondents were $36.9 \%$.

274 responses

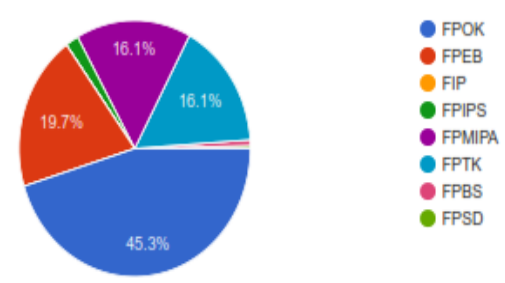

Figure 2. Percentage of Respondents by Faculty

Based on the distribution of the faculties of the eight faculties within the University of Education Indonesia, the following percentages were obtained for the faculty of sports and health education (FPOK) of $45.3 \%$, the faculty of economics and business education (FPEB) of $19.7 \%$, the faculty of technical 
and vocational education (FPTK) of $16.1 \%$, faculty of mathematics and natural sciences education (FPMIPA) $16.1 \%$, faculty of social science education (FPIPS) $1.8 \%$, faculty of language and literature education (FPBS) $0.7 \%$, faculty of arts education and design (FPSD) by $0.2 \%$, faculty of education (FIP) by $0.2 \%$.

\section{CONCLUSION}

Based on the results of the analysis and interpretation of research, it can be concluded as follows: Lifestyle or lifestyle of students in the Indonesian Education University during the Covid19 Pandemic showed poor results where out of a total of 274 respondents 38\% were in the low category and there were even 2 respondents in the dangerous zone category, and only a total of $13 \%$ are in ideal conditions and $48 \%$ are in the sufficient category. The Covid-19 pandemic has greatly disrupted the stability of lifestyle conditions through the parameters measured, namely the condition of family and friends, physical activity, nutritional or nutritional intake, cigarette consumption, alcohol consumption, sleep quality and stress levels, personality, ability to understand events, and satisfaction with career.

\section{ACKNOWLEDGEMENT}

Research related to lifestyle for students at the Indonesian Education University to be able to make descriptions and recommendations on student activities during the COVID-19 pandemic to create healthy students and generations.

\section{REFERENCES}

Côté, Jean, and David J. Hancock. 2016. "Evidence-Based Policies for Youth
Sport Programmes." International Journal of Sport Policy 8(1): 51-65.

Danish, Steven, Tanya Forneris, Ken Hodge, and Ihirangi Heke. 2004. "Enhancing Youth Development through Sport." World Leisure Journal 46(3): 38-49.

Darajat, J. K.N., Nuryadi, and A. Gumilar. 2017. "The Effect of Physical Fitness and Healthy Behavior toward Concentration, Anxiety and Cortisol Hormone." In IOP Conference Series: Materials Science and Engineering,.

Forneris, Tanya, Meredith A. Whitley, and Bryce Barker. 2013. "The Reality of Implementing Community-Based Sport and Physical Activity Programs to Enhance the Development of Underserved Youth: Challenges and Potential Strategies." Quest 65(3): 31331.

Gould, Daniel, and Dana K. Voelker. 2010. "Youth Sport Leadership Development: Leveraging the Sports Captaincy Experience." Journal of Sport Psychology in Action 1(1): 1-14.

Hallal, Pedro C et al. 2012. "Global Physical Activity Levels: Surveillance Progress, Pitfalls, and Prospects." The lancet 380(9838): 247-57.“Katalog BPS : 4501001."

Lippi, Giuseppe, Brandon M Henry, and Fabian Sanchis-Gomar. 2020. "Physical Inactivity and Cardiovascular Disease at the Time of Coronavirus Disease 2019 (COVID-19)." European journal of preventive cardiology 27(9): 906-8.

Ma'mun, Amung. 2016. "Pembudayaan Olahraga Dalam Perspektif Pembangunan Nasional Konsep, Strategi, Dan Implementasi Kebijakan.” Jurnal Pendidikan Sains Sosial dan Kemanusiaan 9(1): 65-88.

Marichi, Ram Bhagat et al. 2020. "Direct Hydrothermal Treatment of Sugarcane Juice for 3D Oxygen-Rich Carbon Aerogel/NiCo2O4 Based Supercapacitor." Materials Chemistry and Physics 239: 121957.

Nuryadi et al. 2019. "Response of Cortisol Hormone to Students' Anxiety and Focus." Journal of Engineering Science and Technology 14(6): 3185-93.

Nuryadi, Nuryadi, Jajat Darajat Kusumah 
Negara, and Lucky Angkawidjaja Roring. 2015. "Respon Hormon Kortisol Terhadap Kecemasan Dan Konsentrasi: Studi Kasus Pada Siswa SMA Yang Tidak Berolahraga, Olahraga Beregu, Dan Olahraga Individu." SIPATAHOENAN 1(1).

Peçanha, Tiago, Karla Fabiana Goessler, Hamilton Roschel, and Bruno Gualano. 2020. "Social Isolation during the COVID-19 Pandemic Can Increase Physical Inactivity and the Global Burden of Cardiovascular Disease." American Journal of Physiology-Heart and Circulatory Physiology.

Purwanto, Agus et al. 2020. "Impact of Work from Home (WFH) on Indonesian Teachers Performance during the Covid19 Pandemic: An Exploratory Study." International Journal of Advanced Science and Technology 29(5): 623544.

Ruiz-Roso, María Belén et al. 2020. "Covid19 Confinement and Changes of Adolescent's Dietary Trends in Italy, Spain, Chile, Colombia and Brazil." Nutrients 12(6): 1807.

Xiang, Mi, Zhiruo Zhang, and Keisuke Kuwahara. 2020. "Impact of COVID-19 Pandemic on Children and Adolescents' Lifestyle Behavior Larger than Expected." Progress in cardiovascular diseases 63(4): 531. 